\title{
В.П. Решетило
}

Харківський національний університет міського господарства імені О.М. Бекетова, Украӥна

\section{ПРОБЛЕМИ ТЕРИТОРІАЛЬНОГО ВИРІВНЮВАННЯ В УМОВАХ ІНКЛЮЗИВНОГО РОЗВИТКУ}

Досліджуються проблеми формування нових інституиіональних умов територіального вирівнювання в розрізі необхідності переходу країни до інклюзивного розвитку. Розглядаються такі важливі фактори досягнення иілей інклюзивного розвитку, як децентралізаиія в управлінні та розвитку регіонів, особливості «вітчизняної моделі децентралізацї̈, становлення об'єднаних територіальних громад, а також напрями реалізаиії конщепції інклюзивного розвитку на рівні регіонів.

Ключові слова: територіальне вирівнювання, інклюзивний розвиток, децентралізаиія, об'єднані територіальні громади, економічна політика, комплексні регіональні програми.

\section{Постановка проблеми}

Проблема територіального вирівнювання, подолання диференціації в рівнях соціальноекономічного розвитку регіонів все ще залишається для України невирішеною, а значить актуальною. Більш того, розрив між регіонами України в соціально-економічному розвитку в останні роки все більше зростає. Так, якщо у 1995 р. показники валової доданої вартості в розрахунку на 1 особу між регіонами - лідерами та регіонами-аутсайдерами відрізнялись у 2,5 раза, у 2010 р. розміри валового регіонального продукту були асиметричними у 3,1 раза, у 2014 p. - у 3,8, то у 2015 р. просторова поляризація в країні склала 6,1 рази (у фактичних цінах відповідних років)[ 1]. Якщо у 2000p. зазначені показники були нижчими за середні по країні у 18 регіонах, у 2015p. їх стало вже 20 [1].

Збільшення рівня регіональної диференціації відбувається на фоні зменшення величини ВВП України порівняно з 2013 роком, а також зменшення порівняно з цим же періодом показника ВВП в доларовому еквіваленті в розрахунку на одну особу за паритетом купівельної спроможності. Якщо у 2000 2005 pр. Україна мала тотожні показники ВВП в доларовому еквіваленті в розрахунку на одну особу 3 Польщею, Словаччиною, Туреччиною, то нині вона випереджає лише країни Середньої Азії [1].

\section{Аналіз останніх досліджень і публікацій}

Проблемам диференціації в рівнях соціальноекономічного розвитку багатих і бідних регіонів і країн, їх територіального вирівнювання присвячені роботи великої кількості як зарубіжних, так і вітчизняних економістів, серед яких слід особливо відзначити праці Д. Аджемоглу, О. Алимова, О. Амоші, О. Бородіної, Б. Буркинського, О. Власюка, 3. Вар- налія, В. Гейця, А. Гриценка, Д. Деттера, Б. Данилишина, М. Долішнього, С. Дорогунцова, В. Загорського, В. Мікловди, С. Пирожкова, Е. Райнерта, Дж. Робінсон, В. Симоненка, В. Сіденка, С. Фьольстера, М. Чумаченка, Л. Чернюк та інших. Особливий інтерес для дослідників становлять роботи Д. Аджемоглу і Дж. Робінсон [2] та Е. Райнерта [3], які активно вивчаються і обговорюються в усьому світі.

Але 3 огляду на все більше поширення концепції інклюзивного розвитку і формування таких трендів, як мережизація, інтелектуалізація та діджиталізація суспільно-економічних процесів, виникає необхідність дослідження впливу цих процесів на проблеми територіального вирівнювання. У 2018 р. Всесвітній економічний форум здійснив аналіз інклюзивності розвитку 103 країн, серед яких 28 належать до групи розвинутих країн і 75 - до країн, що розвиваються (як відомо, за класифікацією Світового банку, Україна входить до групи країн, що розвиваються). За результатами цього дослідження, серед розвинутих країн за рівнем інклюзивності економічного зростання до п'ятірки країн - лідерів увійшли Норвегія, Ісландія, Люксембург, Швейцарія і Данія. Групу країн, що розвиваються, очолили Литва, Угорщина, Азербайджан, Латвія і Польща. Україна за рівнем інклюзивності економіки посіла загальне 78 місце із 103 країн. Перед Україною - Гондурас, Пакистан і Танзанія, за нею йдуть Йорданія, Киргизстан, Гана та Камерун [4]. Таким чином для України, розробка комплексу заходів по підвищенню інклюзивності розвитку, справедливості і стійкості має особливо важливе значення.

I хоча в Україні діс система державних мінімальних соціальних стандартів, проте соціальні нормативи існують самі по собі і ніяк не ув'язуються 3 економічним прогресом. Спостерігається і вкрай не 
гармонійний розподіл доходів між усіма суб’єктами, що поглиблює розшарування населення. Стандарти інклюзивного розвитку в країні лише починають розроблятися, і лише на загальнодержавному рівні. Разом з цим, реальний рух до стійкого інклюзивного розвитку економіки регіонів неможливий без ефективних реформ, що потребує поглиблення інституціональних перетворень, створенням системи ефективних ринкових інститутів і їх активної взаємодії як на загальнодержавному, так і регіональному рівHi.

Метою даної статті $є$ дослідження передумов підвищення рівня інклюзивності економіки України та іiі регіонів, пошук шляхів формування нових інституціональних умов територіального вирівнювання в розрізі необхідності переходу країни до інклюзивного розвитку.

\section{Виклад основного матеріалу}

Інклюзивний розвиток - досить нова концепція економічного зростання, яка актуалізувалась в останні роки. Найбільш активно над цією концепцією працюють здебільшого такі зарубіжні вчені як Д. Аджемоглу, 3. М. Бедос, С. Голандер, Дж. Робінсон Е. С. Райнерт, Дж. Подеста. Серед українських науковців цікавими є роботи I. Бобуха, В. Геєця, А. Гриценко, I. Манцурова, О. Прогнімак, С. Щегеля та інших [1-12].

Формування концепції інклюзивного розвитку пов'язано 3 тим, що, як показує світова практика, лише економічного зростання недостатньо, щоб говорити про ефективний розвиток держави. Макроекономічні показники країни можуть збільшуватись, але водночас значна частина населення не бере участь у створенні ВВП, а відповідно і у розподілі, не «включена» в процес економічного зростання. Тому на сьогодні інклюзивне зростання розглядається як основа соціально-економічного розвитку країни через інклюзію усіх членів суспільства в процеси соціально-економічного розвитку та їх гуманізацію. Концепція інклюзивного розвитку передбачає, що кожен суб'єкт економіки є важливим, унікальним, цінним для суспільства і має можливості, щоб задовольнити свої потреби.

Поняття інклюзія (англ. inclusion - включення, залученість) - має широке значення, і реалізоване в багатьох аспектах. В економічній літературі розглядаються поняття «інклюзивне зростання», «інклюзивні інновації», «інклюзивний розвиток», «інклюзивна економіка» тощо. Існує і досить багато визначень поняття «інклюзивний розвиток». Так, вчені Світового банку визначають: інклюзивний розвиток - це сталий швидкий розвиток усіх галузей економіки, що залучає значну частину трудових ресурсів країни і характеризується рівністю можливостей у доступі до ринку праці та ресурсів [5]. При цьому головний акцент робиться на продуктивній зайнятості всіх груп працездатного населення (включаючи жінок) як важливої умови зниження рівня бідності. Саме скорочення бідності та нерівності є головною метою інклюзивного розвитку. В його основі лежить необхідність забезпечення участі всіх верств населення країни у процесі зростання як з точки зору прийняття рішень, так і у формуванні факторів зростання. Повинні бути створені рівні можливості для усього населення в реалізації власного людського потенціалу незалежно від місця проживання і соціально-економічних умов, статі і віку.

Таким чином, інклюзивне зростання має ширші цілі, ніж збільшення ВВП, воно спрямоване на розвиток людини, підвищення їі добробуту та зниження рівня бідності та нерівності, вимагає активної участі в економіці людського ресурсу, а також підкреслює, що населення країни повинно впливати не лише на результати розподілу ВВП, але й на його виробництво [6].

Як відомо, індекс інклюзивного розвитку базується на 12 індикаторах, об'єднаних в три групи:

- $\quad$ зростання і розвиток (включаючи зростання ВВП, зайнятості, продуктивності праці, очікуваної тривалості життя);

- $\quad$ інклюзивність (медіанний дохід домогосподарств, рівень бідності і нерівності);

- справедливість і стійкість (рівень заощаджень, демографічного навантаження, державного боргу і забруднення довкілля) [4].

Країни ЄС поставили завдання інклюзивного розвитку в центр програми «Свропа - 2020». Зокрема, в якій зазначається, що зростання має бути інтелектуальним, сталим та інклюзивним, базуватися на залученні до відповідних процесів усіх секторів економіки, усіх верств суспільства для досягнення високого рівня зайнятості, продуктивності та соціальної єдності [7, с. 189-190].

Для реалізації цих пріоритетів було сформовано пакет з п'яти цілей у таких сферах: зайнятість, інновації, зміна клімату та енергетика, освіта, боротьба проти бідності та соціального відчуження. Для досягнення згаданих цілей для кожної країни ЄС як пріоритетні висунуті такі напрями діяльності.

1. Інноваційний союз.

2. Рух молоді.

3. Розвиток цифрових технологій в Свропі.

4. Доцільне використання ресурсів в Свропі.

5. Індустріальна політика, спрямована на глобалізацію.

6. План з розвитку нових здібностей і збільшення кількості робочих місць.

7. Свропейська політика проти бідності [7, c. 189-190].

Таким чином, основними цілями інклюзивного зростання $\epsilon$ : 
- $\quad$ не просто збільшення ВВП, але й всебічний розвиток людського капіталу;

- $\quad$ високий рівень зайнятості населення, інвестування в освіту та охорону здоров'я;

- скорочення нерівності та бідності, вдосконалення системи соціального захисту, підвищення якості життя громадян, особливо найбільш незахищених верств населення: дітей, жінок, людей похилого віку;

- $\quad$ розвиток соціальної активності, підвищення участі громадян в економічному житті, а не тільки в розподілі та споживанні доходу;

- $\quad$ захист навколишнього середовища, підвищення ефективності використання природних ресурсів, перехід економіки на «зелені принципи»;

- $\quad$ поширення переваг економічного зростання на всі регіони країни, територіальна єдність країни 3 позицій рівня економічного розвитку та якості життя;

- територіальне вирівнювання та усунення регіональних диспропорцій.

В контексті нашого дослідження особливого значення набувають два останні положення щодо цілей інклюзивного розвитку, в яких підкреслюється посилення ролі всіх територій в вирішенні проблем економічного зростання. Таким чином, до процесу інклюзивного розвитку повинні бути залучені всі сектори економіки (не тільки високотехнологічні) та всі складові інфраструктури країни, а також всі регіони та території.

Ефективність інклюзивного розвитку регіонів в визначальній мірі залежить від структурної, інвестиційної, інституціональної, соціальної, природоохоронної, фінансової, зовнішньоекономічної регіональних політик. Від того, наскільки збалансовані ці політики, залежить комплексний пропорційний розвиток регіональної економіки. Це обумовлено тим, що регіон $\epsilon$ не тільки підсистемою соціальноекономічного комплексу країни, а й відносно самостійною його частиною із закінченим циклом відтворення, особливими формами прояву стадій відтворення й специфічними особливостями соціальних $\mathrm{i}$ економічних процесів.

У контексті досягнення цілей інклюзивного розвитку дуже актуальною для України є проблема подолання диспропорційності соціальноекономічного простору, зменшення між- та внутрішньо регіональних асиметрій. На це була спрямована Державна стратегія регіонального розвитку на період до 2020 року, в якій зазначена необхідність «досягнення рівномірного та збалансованого розвитку територій, розвиток міжрегіонального співробітництва, запобігання поглибленню соціальноекономічних диспропорцій шляхом формування «точок зростання», активізації місцевої економічної ініціативи та зміцнення потенціалу сільської місце- вості, забезпечення соціально-економічної єдності і рівномірності розвитку регіонів з метою створення рівних умов для розвитку людини» [8].

Одним із шляхів досягнення поставлених цілей стала децентралізація в управлінні та розвитку регіонів. Децентралізація дійсно створює нові можливості для ефективної роботи системи управління на місцевому рівні та підвищення якості публічних послуг, однак вона несе й певні загрози, пов'язані 3 посиленням асиметрії розвитку територіальних громад, коли багаті громади стають багатшими, а бідні - біднішими. Багато досліджень свідчить про те, що кожна країна і їі регіони можуть скористатися шансом, який їм дає децентралізація, і або перейти на новий щабель розвитку, або поглибити існуючі територіальні диспропорції [9]. Тобто одним з основних ризиків децентралізації $\epsilon$ ймовірність поглиблення рівня депресивності та посилення нерівності доходів через зміну структури державних видатків. Аналіз процесів децентралізації у світі в цілому та в Європі зокрема, дозволяє виокремити ряд тенденцій, які склалися протягом останнього десятиліття.

По-перше, не існує прямої залежності між рівнем розвитку країни та ступенем фінансової децентралізації, проте заможніші держави схильні до більш глибокої децентралізації. Це можна пояснити тим, що багаті країни, які мають високий рівень бюджетних доходів у розрахунку на одного жителя, можуть дозволити органам влади на місцях залишати більшу частку бюджетних доходів для фінансування власних потреб. Тому серед успішних європейських країн (з ВВП понад 40 тис. євро на 1 особу) найвищий рівень доходів місцевих бюджетів (у відношенні до ВВП) станом на 1 січня 2016 р. був у Данії (35,2\%), Швеції (24,8\%), Фінляндії (22,3\%) та Норвегії $(15,7 \%)$ [10, с. 54].

По-друге, спрямованість процесів децентралізації в різних країнах світу є різною. Якщо Данія, Швеція, Фінляндія, Румунія, Естонія, Болгарія та Словенія у 2004 - 2015 рр. поглиблювали децентралізацію, то Нідерланди, Великобританія, Литва, Угорщина, Люксембург та Ірландія посилювали централізацію.

По-третє, у різних країнах можуть бути різними і мотиви децентралізації. В одних країнах це можуть бути виключно економічні мотиви ( Греція, Італія, Португалія), коли метою децентралізації $є$ досягнення макроекономічної стабільності, або необхідність покрашення рівня освіти, медицини та досягнення інших цілей інклюзивного розвитку. В країнах Східної Свропи децентралізація пов'язана здебільшого з політичними мотивами, з намаганнями демократизувати політичну систему.

По-четверте, результативність децентралізації значною мірою визначається інституціональними факторами, до яких належать рівень активності гро- 
мад і громадян у прагненні реалізувати власні інтереси та проекти економічного розвитку, наявність правових інститутів і фінансових ресурсів, ступінь впровадження інститутів стимулювання соціально економічної активності територіальних громад.

В Україні реалізація першого етапу децентралізації влади призвела до формування свого роду «вітчизняної моделі децентралізації», яка характеризується переданням територіальним громадам соціальних функцій держави (фінансування освіти, медицини, інфраструктури, соціальної допомоги), однак без фінансового забезпечення цих програм і створення умов для економічного зростання регіонів. Така «децентралізація» державної політики не тільки не забезпечує зниження асиметричності розвитку територіальних громад, але й поглиблює соціальну напругу в суспільстві. Якщо ж в цілому оцінювати рівень децентралізації влади та державних фінансів в Україні на фоні світового i, зокрема, європейського досвіду, то можемо дійти висновку: сьогодні Україна є найбільш централізованою країною Східної Європи і характеризується низьким рівнем деце-

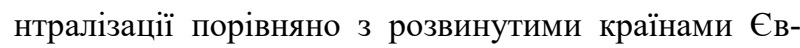
ропи та світу [10, с.57].

Тому для України одночасно є важливими два питання: 1) перерозподіл бюджетного ресурсу і повноважень на місцевий рівень, і принципові зміни фінансової бази державного управління взагалі; 2) забезпечення інклюзивного і сталого економічного зростання, збільшення ВВП і, відповідно, зменшення територіальних диспропорцій в якості і рівні життя населення, і рівні розвитку людського потенціалу.

При цьому важливо враховувати, що регіон - це цілісна соціально-економічна та інституціональна система із своїми структурою, функціями, зв'язками iз зовнішнім середовищем, історією, культурою, умовами життя населення, а будь які інституціональні перетворення знаходяться на межі між економікою, правом, політикою, культурою і відображають їх взаємний вплив один на одного. Політичні інституційні перетворення пов'язані 3 появою нових політичних інститутів, що забезпечують поглиблення демократизації суспільства, становлення громадянського контролю, посилення громадянських ініціатив. Інституційні зміни правової системи пов'язані з необхідністю швидкої адаптації законодавства до процесів формування інноваційної економіки і громадянського суспільства. Соціальний напрям інституційних змін визначається зміною менталітету населення, зростанням його самосвідомості і ініціативності, збільшенням його довіри до держави і його інститутів. Все це практично унеможливлює просте копіювання чужого досвіду та вимагає всебічного урахування особливостей соціально-економічного та політичного розвитку кожного регіону і країни в цілому.
Зокрема, децентралізація владних повноважень потребує концентрації діяльності інститутів місцевого самоврядування, інститутів громадянського суспільства, місцевих органів виконавчої влади на ефективному використанні ресурсів та факторах інклюзивного розвитку, на нових формах територіальної організації господарства, на реалізації можливостей територіальних громад в підвищенні якості життя населення. Динамічний розвиток ряду країн, зокрема Угорщини, Чехії, Словаччини, Польщі доводить, що найбільш ефективними є виключно інноваційні структури, які дозволяють задіяти ресурсний потенціал територіальних громад, сформувати нові робочі місця та наповнювати місцеві бюджети завдяки використанню власних можливостей. Такими новітніми територіально-виробничими формами інноваційного розвитку регіональних господарських систем є технопарки, технополіси, бізнес - інкубатори, кластери, індустріальні парки, логістичні платформи, які поки що не стали у нашій державі факторами структурних перетворень у регіональній економіці. Інституціональною основою таких перетворень $є$ Закон України «Про інноваційну діяльність», відповідно до якого до компетенції обласних і районних рад віднесено: затвердження регіональних інноваційних програм, фінансування яких здійснюється через державні інноваційні фінансовокредитні установи (ї регіональні відділення), визначення коштів бюджету для їх фінансової підтримки, контроль за використанням бюджетних коштів. До компетенції представницьких органів місцевого самоврядування (сільські, селищні, міські ради) віднесено затвердження місцевих інноваційних програм та відповідним чином забезпечення їх реалізації, фінансової підтримки в межах коштів бюджету розвитку; створення комунальних інноваційних фінансово-кредитних установ для фінансової підтримки місцевих інноваційних програм за кошти місцевих бюджетів, затвердження їх статутів чи положень про них.

Таким чином, інклюзивний розвиток регіонів потребує формування інвестиційно - інноваційної інфраструктури регіону, яка повинна об'єднувати інвестиційну та інноваційну діяльність в єдине ціле 3 метою створення інноваційних виробництв та сучасних робочих місць, що і $є$ об'єктивною основою підвищення рівня розвитку регіонів та доходів населення, яке там проживає. У вимірі цілей інклюзивного розвитку (а саме продуктивної зайнятості, гідного рівня оплати праці, різноманітних соціальних проектів розвитку громад тощо), особливо вагому соціальну роль виконують креативна індустрія та сфера інформаційних технологій, які здатні заохочувати технологічні інновації, інвестувати в людський капітал, мобілізувати таланти і навички значної кількості людей. Все це потребує розробки стратегії 
та конкретної програми інвестиційно - інноваційного розвитку регіону.

В процесі децентралізації в Україні виникла нова інституціональна одиниця - об'єднані територіальні громади, які створюються на основі Методики формування спроможних територіальних громад, затвердженої Постановою Кабінету Міністрів України [11]. Однак, дана методика передбачає формування неприпустимо великих територіальних громад, що збільшує розрив між громадянином та владою, і зменшує доступність публічних послуг. «Методика» фактично нехтує основоположними принципами Європейської хартії місцевого самоврядування, ратифікованої відповідним Законом України, зокрема, щодо прав громадян на участь в управлінні державними справами, що найкраще може здійснюватися саме на місцевому рівні, а також ефективного i близького до громадянина управління, яке реалізується через органи місцевого самоврядування [11]. Як наслідок, спостерігаємо підвищення рівня концентрації ресурсів і потенціалу в обласних центрах 3 одночасним прискоренням процесу деградації в регіональній соціально - економічній системі, тобто існує загроза поглиблення територіальних соціально-економічних диспропорцій внаслідок просторової експансії великих міст.

Одночасно, для багатьох мешканців територіальних громад, населені пункти яких віддалені від центру на десятки кілометрів, втрачається сутність громади, об'єднаної спільними інтересами і відчуттям причетності до вирішення певних актуальних проблем, що повністю суперечить цілям інклюзивного розвитку. Відповідно, головна мета реформи підвищити ініціативу мешканців і залучити населення до вирішення питань розвитку громади - так і не досягнута. 3 позицій інклюзивного розвитку, інститут об'єднаних територіальних громад, що формується в країні, в більшості випадків не забезпечує широкої участі громадян у процесах життєдіяльності територіальних громад та управління ними, не формує ефективних механізмів виробництва і розподілу доходів, і зокрема бюджетних коштів, не призводить до ефективного вирішення проблем підвищення якості життя населення регіонів, особливо сільських.

Слід також підкреслити, що існуючі в Україні інституціональні прогалини, відсутність ефективних суспільних інститутів не дозволили сформувати систему громадянського контролю над економічною і політичною діяльністю олігархів та їх бізнесструктур, які на регіональному рівні залишаються практично безконтрольними, що принципово стримує рух країни до інклюзивного розвитку. При цьому відповідну додаткову ренту отримують олігархи на тих територіях, де є джерела для отримання рентних доходів (природні ресурси місцевого значення
- газ, корисні копалини, бурштин, важливі транспортні магістралі), та ті, які користуються перевагами розташування поблизу великих міст ( що багаторазово збільшує вартість землі). Тому на інституціональному рівні слід підвищити рівень відповідальності органів місцевого самоврядування за ефективне використання наявних ресурсів в інтересах всієї громади, досягти гармонізації місцевих, регіональних і загальнодержавних інтересів у цій сфері.

Важливим інституціональним фактором інклюзивного розвитку регіонів $є$ ефективна економічна політика. Формування інститутів державного регулювання регіонального розвитку $\epsilon$ надскладною проблемою. В той же час і зарубіжний і вітчизняний досвід доводить, що ефективна регіональна політика здатна давати значні результати. Саме на регіональному рівні стратегічні завдання державного регулювання соціально-економічним розвитком конкретизуються і набувають певної специфіки.

Відносно до сучасних вимог завдання державного регулювання регіональним розвитком полягають у наступному:

- $\quad$ забезпечення регіональної економічної безпеки, підтримка відповідного рівня виробництва стратегічної продукції;

- підтримка найважливіших макроекономічних пропорцій методами фіскальної і монетарної політики;

- регулювання необхідного співвідношення між кількістю і якістю робочих місць і пропозицією робочої сили по окремим контингентам населення, містам і районам;

- $\quad$ розвиток соціальної інфраструктури і створення загальних умов господарювання для всіх секторів економіки;

- $\quad$ забезпечення можливостей функціонування в регіоні енергетичних і транспортних систем;

- компенсація для соціально значимих сфер діяльності і підприємств певних втрат від негативних факторів їх діяльності;

- $\quad$ комплексне вирішення проблем регіону на основі реалізації взаємозв'язаної системи регіональних цільових програм.

Підкреслимо, що державне регулювання регіональним розвитком має бути системним, непрямим, рекомендаційним і головне - стратегічним. Для реалізації планів, програм і прогнозування соціальноекономічним розвитком держава повинна надати регіонам систему перспективних стратегічних документів. Серед них повинна бути довгострокова стратегічна концепція соціально-економічного розвитку країни в цілому; економічні, соціальні і ресурсні прогнози; стратегічний план соціальноекономічного розвитку окремого регіону, в якому повинна бути розвернута його стратегічна концепція на період найближчих 10-15 років; середньостроко- 
ва програма дій адміністрації по стабілізації і подальшому розвитку регіону на 3 - 4 роки; цільові інвестиційні програми і інноваційні проекти; річні прогнози соціально-економічного розвитку, розроблені в єдиній системі прогнозів країни; короткострокові програми розвитку регіону (до 1 року).

Інститут державного регулювання соціальноекономічним розвитком регіонів, його форми і методи, на сьогодні є недостатньо ефективним та системним. Найбільш проблемним питанням є нестабільність і не прогнозованість державної економічної політики, яка змінюється в Україні після кожної революції та зміни складу урядів. Ефективна державна регіональна політика потребує чітко установлених стратегічних цілей і задач довгострокового соціально-економічного розвитку, розробки антикризової державної політики, встановлення оптимального співвідношення всіх гілок влади, підтримки регіональної економічної безпеки, певної стабільності в проведення фіскальної та монетарної політики, невтручання в оперативну діяльність місцевих органів влади.

Соціально-економічна політика регіону - це певні цілі і принципи дії адміністрації і регіональних економічних суб'єктів, а також напрями та пріоритети їх діяльності, які базуються на загальнонаціональній стратегії і враховують загальнодержавні інтереси. Традиційно в зарубіжних країнах регіональне управління зосереджується на вирішенні наступних завдань:

- $\quad$ пропорційний розвиток місцевої економіки;

- $\quad$ збереження старих та створення нових робочих місць на основі залучення інвестицій;

- забезпечення прибуткової бази місцевих бюджетів;

- $\quad$ раціональне землекористування;

- структурна перебудова старих індустріальних районів;

- покращення екологічної ситуації;

- $\quad$ розвиток професійної освіти у відповідності з потребами регіону, перепідготовка та перекваліфікація кадрів;

- допомога бідним територіям.

У стабільній соціально-економічній ситуації стратегічний план соціально-економічного розвитку окремого регіону, в якому розвернута його стратегічна концепція на період найближчих 10 - 15 років, та середньострокова програма дій адміністрації по стабілізації і подальшому розвитку регіону на 3 - 4 роки, повинні стати основними інструментами управління регіоном. Такі комплексні адресні плани, що охоплюють всю регіональну економіку, повинні включати індикативні показники і цільові орієнтири, систему регіональних завдань, перелік регіональних проектів і програм, контрольні баланси виробництва і розподілу стратегічно важливих ресурсів і продук- тів, стратегічну прогнозну інформацію, систему стабільних економічних, фінансових, соціальних, екологічних нормативів, та інші інструменти регуляторного впливу.

Для покращення ефективності функціонування інституту регіональної економічної політики необхідно сконцентрувати зусилля на виявленні економічних інтересів регіонів, на співвідношенні і взаємодії різноманітних зовнішніх і внутрішніх факторів стратегічного розвитку регіонів, розробці технології, організації і методів загальнонаціонального i регіонального прогнозування i планування нової якості інклюзивного розвитку.

Слід зазначити, що в нинішніх умовах регіонам необхідно все більше ставати самостійними суб'єктами економіки та збільшувати прибутковість комунальних фінансово - кредитних установ, уміти визначати прибуткові регіональні напрями, які при регіональній фінансовій підтримці дадуть прибуток в різні періоди часу. Такі дії мають потужний мільтиплікуючий ефект, оскільки рекапіталізація отриманих прибутків дає поштовх до циклічного руху капіталу в нових перспективних регіональних проектах. Це дає змогу активізувати фінансовий регіональний ринок на основі власних ресурсів. Але для цього необхідно збільшити повноваження регіональної влади згідно політики децентралізації і надати місцевим адміністраціям більшу свободу дій (у встановлених межах). При цьому важливим $є$ використання досвіду проведення державної регіональної політики європейського зразка з чітким розмежуванням повноважень між ланками управління та між державними органами влади і місцевим самоврядуванням.

\section{Висновки}

Таким чином, для досягнення мети інклюзивного розвитку ефективний комплексний розвиток регіону повинен мати певну науково - методичну основу. Інклюзивна модель економічного розвитку передбачає створення максимальних можливостей для розвитку особистості, іiі участі у всіх сферах життєдіяльності країни, працевлаштування та рівний доступ до результатів праці. Пріоритетом інклюзивного розвитку $є$ підвищення якості життя населення за рахунок формування економіки 3 високою зайнятістю та суспільства 3 його мінімальним розшаруванням. Досягнення цих завдань не можливе лише зусиллями держави. Вони повинні бути перенесені на регіональний рівень, але при умові проведення ефективної регіональної політики, розширення повноважень на місцях, створення фінансових умов для інноваційного розвитку регіонів.

Важливими недоліками, що стримують інклюзивний розвиток регіонів $є$ : безсистемність та непослідовність формування державної економічної по- 
літики; недостатня нормативно - правова підтримка діяльності господарюючих суб'єктів; відсутність державної системної підтримки інклюзивного розвитку на регіональному рівні; низький рівень фінансування на створення нових робочих місць в регіонах; відсутність інституційних умов взаємовідносин між учасниками; відсутність адекватного потребам інклюзивного розвитку реформування освіти; відсутність капіталовкладень в інновації.

3 переходом до інклюзивного стійкого зростання необхідно розробляти нові стандарти інклюзивного розвитку. Найважливішими стандартами інклюзивного розвитку регіонів, які мають бути закріплені правовими нормами, можуть на першому етапі бути наступні нормативи:

- доля ВРП (у процентному відношенні), що направляються на фінансування охорони здоров'я в частині надання безкоштовних медичних послуг (але не нижче визначеного в законі рівня);

- доля ВРП (у процентному відношенні), що направляються на фінансування безкоштовної для громадян освіти (але не нижче визначеного в законі рівня).

Запропоновані нормативи забезпечать реалізацію ключових моментів інклюзивного зростання: усесторонній розвиток людського капіталу, скорочення нерівності і бідності, рівність можливостей людей в доступі до ресурсів. I, нарешті, необхідно після відповідних розрахунків індексів інклюзивного розвитку спостерігати за їх динамікою і розробляти відповідні національні програми і пропозиції по проведенню структурної політики як держави, так і окремих регіонів.

Перспективи подалыших розвідок у даному напрямку повинні бути направлені на дослідження проблем відповідного збалансування політики та дій всіх органів влади, як загальнодержавного, так і місцевого рівнів, для забезпечення динамічного людиноцентричного зростання. Необхідні подальші дослідження шляхів досягнення рівноваги між економічною ефективністю, соціальною результативністю та екологічними обмеженнями, що висуваються до процесу сучасного господарювання як на загальнодержавному рівні, так і на рівні окремих регіонів. В основі інклюзивного соціально-економічного розвитку повинні лежати процеси активізації інвестиційно - інноваційної діяльності в регіоні як системи методів та механізмів впливу на регіональних суб'єктів господарювання, та всебічний розвиток людського капіталу.

\section{Література}

1. Держсавна служба статистики Украӥни : Офіиійтий сайт [Електронний ресурс]. - Режим доступу: http: //www. ukrstat. gov. ual operativ/ operativ 2020/ni/zndr2017.doc - Назва з екрану.

2. Аджемоглу, Д. Почему одни страны богатые, а дру- гие бедные [Текст] / Д. Аджемоглу, Дж. А. Робинсон. Происхождение власти, процветания и нищеты. - М. : ACT, 2015. $-720 \mathrm{c}$.

3. Райнерт, Э.С. Как богатые страны стали богатыми, и почему бедные страны остаются бедными; пер. с англ. Н. Автономовой [Текст] / Э.С. Райнерт. - М.: Изд. дом Гос. ун-та Высшей школы экономики, 2014. - 384 с.

4. Индекс инклюзивного развития 2018: Всемирный экономический форум в Давосе [Электронный ресурс]. - Режим docmyna: http: //www.econominews.ru/ mirovajajekonomika/524-indeks-inkljuzivnogo-razvitija-2018vsemirnyjj.html. - Загл. с экрана.

5. Ranieri, R., Ramos, R.A. Inclusive Growth: Building up a Concept. Working Paper No. 104, International Policy Centre for Inclusive Growth. Retrieved from http://www.ipc\&undp.org/pub/IPCWorkingPaper104.pdf.

6. Hollander, S., Bolling, R. Practice, don't preach: getting serious about inclusive development. Retrieved from http://www.thebrokeronline.eu/Articles/Practice\&don\&t\&prea ch\&getting\&serious\&about\&inclusive\&development.

7. Прогнімак, О.Д. Інклюзивний розвиток Украӥни: перешкоди vs перспективи [Текст] / О.Д. Прогнімак // Економічний вісник Донбасу. - 2018. - № 1(51). - С. 187-197.

8. Державна стратегія регіонального розвитку на період до 2020 року : затверджена Постановою Кабінету Міністрів Украӥни від 06.08.2014 p. № 385 [Електронний ресурс]. - Режим доступу: http://zakon2.rada.gov.ua/laws/show/385\$2014\$\%D0\%BF. .Назва з екрану.

9. Prud'homme, R. (1995). The dangers of decentralization. The World Bank Research Observer.10. 201-220 Retrieved from http:// documents. worldbank.org/ curated / en/ 602551468154155279/

pdf/

770740JRN0WBRO0Box0377291B00PUBLIC0.pdf.

10. Сторонянська, I. 3. Просторові асиметрії економічного розвитку в умовах адміністративно-фінансової децентралізації [Текст] / I. 3. Сторонянська, Л. Я. Беновська // Економіка Украӥни. - 2018. - № 2. - С. 50-66.

11. Про затвердження Методики формування спроможних територіальних громад: Постанова Кабінету Міністрів Украӥни від 08.04.2015 р. № 214 [Електронний pecypc]. - Режим доступу: http://zakon3.rada.gov.ua/laws/show/214_2015_\%D0\%BF. Назва з екрану.

12. Бобух, I.М. Стратегічні орієнтири економічного зростання Украӥни: інклюзивність як ключовий пріоритет [Текст] / І.М. Бобух, С.М. Щегель // Вісник Національної академї наук України. - 2018. - № 7. - С. 55-70.

\section{References}

1. The official site of State Statistics Service of Ukraine (2019). Retrieved from

http://www.ukrstat.gov.ua/operativ/operativ2020/ni/zndr2017.doc

2. Acemoglu, D., Robinson, J. (2015) Why Nations Fail. The

Origins of Power, Prosperity and Poverty.

3. Reinert, E.S. (2014). How Rich Countries Got Rich and Why Poor Countries Stay Poor.

4. Index of inclusive development 2018. A world economic forum is in Davos. Retrieved from http://www.econominews.ru/mirovaja-jekonomika/524indeks-inkljuzivnogo-razvitija-2018-vsemirnyjj.html.

5. Ranieri, R., Ramos, R.A. Inclusive Growth: Building up a 
Concept. Working Paper No. 104, International Policy Centre for Inclusive Growth. Retrieved from http://www.ipc\&undp.org/pub/IPCWorkingPaper104.pdf.

6. Hollander, S., Bolling, R. Practice, don't preach: getting serious about inclusive development. Retrieved from http://www.thebrokeronline.eu/Articles/Practice\&don\&t\&prea ch\&getting\&serious\&about\&inclusive\&development.

7. Prognimak, O.D. (2018). Inclusive development of Ukraine: obstacles vs. prospects. Economic bulletin of Donbass. 1 (51), 187-197.

8. State strategy of regional development on a period to 2020 year: ratified Decision of Cabinet Ukraine from 06.08.2014 №385. Retrieved from http://zakon2.rada.gov.ua/laws/show/385\$2014\$\%D0\%BF

9. Prud'homme, R. (1995). The dangers of decentralization. The World Bank Research Observer.10. 201-220 Retrieved from http:// documents. worldbank.org/ curated / en/ 602551468154155279/ pdf/ 770740JRNOWBRO0Box0377291B00PUBLIC0.pdf.

10. Storonynska Iryna, Benovska Liliya. (2018). Spatial asymmetries of economic development in conditions of administrative and financial decentralization. Economy of
Ukraine, 2, $50-66$.

11. About claim of Method of forming of well-off territorial societies: There is a decision of Cabinet Ukraine from 08.04.2015 № 214. Retrieved from http://zakon3.rada.gov.ua/laws/show/214_2015_\%D0\%BF.

12. Bobukh, I.M., Shchegel, S.M. (2018). Strategic environment of economic growth in Ukraine: inclusiveness as a key priority. Bulletin of the National Academy of Sciences of Ukraine, 7, 55-70.

Рецензент: д-р екон. наук, проф. К.А. Мамонов, Харківський національний університет міського господарства імені О.М. Бекетова, Харків, Україна

Автор: РЕШЕТИЛО Валентина Петрівна доктор економічних наук, професор, завідувач кафедри

Харківський національний університет міського господарства імені О.М. Бекетова Украӥна.

E-mail-kafedraekteor@gmail.com

ID ORCID: http://orcid.org/0000-0001-7511-7279

\section{PROBLEMS OF TERRITORIAL ALIGNMENT IN INCLUSIVE DEVELOPMENT CONDITIONS}

V. Reshetilo

O.M. Beketov National University of Urban Economy in Kharkiv, Ukraine

The problems of formation of new institutional conditions of territorial alignment in the context of the need for transition of the country to inclusive development, which requires the inclusion of all members of society in socioeconomic processes and their humanization, are investigated.

It has been determined that inclusive development has broader goals than GDP growth, and aims at comprehensive human development, increasing its well-being and reducing poverty and inequality, and requires active participation in the human resource economy.

It is revealed that the economic literature covers the concepts of "inclusive growth", "inclusive innovation", "inclusive development", "inclusive economy", etc. There are also many definitions of the term "inclusive development". Thus, World Bank scholars have identified: inclusive development is the sustainable rapid development of all sectors of the economy, which attracts a large part of the country's labor resources and is characterized by equal access to the labor market and resources. The priority of inclusive development is to improve the quality of life of the population through the formation of a high-employment economy and a society with a minimal separation. Achieving these goals is not possible only through the efforts of the state. They should be shifted to the regional level, but subject to effective regional policy, expansion of local authority, creation of financial conditions for innovative development of regions.

The importance of strategic state regulation of regional development, which has to be systematic, indirect and advisory, needs to be clearly defined strategic goals and objectives of long-term socio-economic development, development of anti-crisis state policy, establishment of optimal ratio of all branches of power, support of regional economic security, proven implementation of fiscal and monetary policy, non-interference in the operational activities of local authorities.

Such important factors as achievement of the goals of inclusive development are considered, as decentralization in management and development of regions, features of "domestic model of decentralization", formation of new institutional unit - united territorial communities and formation of their innovative structures, and directions of development of effective economic policy of the state and regions. to implement the concept of inclusive development.

Keywords: territorial alignment, inclusive development, institutional transformations, decentralization in governance and development of regions, integrated territorial communities, economic policy, integrated regional programs. 